\title{
Assessment of an Invasive Weed "Maimaio" Commelina foecunda in the Sesame Fields of Western Zone of Tigray, Northern Ethiopia
}

\author{
G. Zenawi $(\mathbb{D}$, T. Goitom $(\mathbb{D}$, and B. Fiseha \\ Tigray Agricultural Research Institute, Humera Agricultural Research Center, P.O. Box 62, Humera, Ethiopia \\ Correspondence should be addressed to G. Zenawi; zenawigg@gmail.com
}

Received 18 June 2018; Revised 30 August 2018; Accepted 4 October 2018; Published 1 November 2018

Academic Editor: Yong In Kuk

Copyright (c) 2018 G. Zenawi et al. This is an open access article distributed under the Creative Commons Attribution License, which permits unrestricted use, distribution, and reproduction in any medium, provided the original work is properly cited.

\begin{abstract}
Sesame (Sesamum indicum L.) is probably the most ancient oilseed. It has multiple uses; it is used as a source of food and in the pharmaceutical and cosmetics industries. The average yield of sesame in western Tigray is too low (about $400 \mathrm{~kg} / \mathrm{ha}$ to $500 \mathrm{~kg} / \mathrm{ha}$ ) due to different factors, and weed infestation takes a lion's share. More than 80 weed species were recorded and identified as weed pests for sesame in western Tigray. "Maimaio" Commelina foecunda is the most troublesome weed of sesame. The purpose of this study was to assess the distribution of $C$. foecunda and quantify its infestations. The survey was conducted in 24 sesame growing areas and 48 sesame farms from the three districts of western Tigray in the 2017 production season. The survey result showed that about $91.7 \%$ of the assessed sesame farms in western Tigray were found infested with C. foecunda. The weed frequently appeared in Kafta Humera. And, it occurred abundantly and closely in Kafta Humera, whereas it occurred poorly and irresolutely in Tsegede. Concentrated frequency, abundance, and density of the weed were recorded by large-scale sesame producers, lower growing altitudes, and early growth stage of sesame; whereas, it was limited in the small-scale farms, higher growing altitudes, and late growth stage of sesame.
\end{abstract}

\section{Introduction}

Sesame (Sesamum indicum L.) belongs to the order Tubiflorae and family Pedaliaceae cultivated for its seed. It is probably the most ancient oilseed known and used by man, so that it is almost impossible to say with any degree of accuracy where and when its domestication took place [1]. Sesame has multiple uses; it is used as a source of food: eaten raw, either roasted or parched, or as blended oil in the form of different sweets. It is also used in the pharmaceutical industry, in the manufacture of margarine and soap, as a fixative in the perfume industry, in cosmetic industry, and as synergist for insecticides. In Ethiopia, sesame is used as cash crop, export commodity, raw materials for industries, and as a source of employment opportunity. A sizable proportion of the population, therefore, generates income from oilseed farming, trade, and processing. Area allocated to sesame both at regional and national level is increasing from time to time. The average yield of sesame in western Tigray is about $400 \mathrm{~kg} / \mathrm{ha}$ to $500 \mathrm{~kg} / \mathrm{ha}$ (personal communication with bureau of agriculture/BoA). There are a number of constraints that limit the productivity of sesame, like pest infestations (weeds, insects, and disease), water logging (poor drainage), lack of optimum plant population, seasonal delay, low yielding varieties, postharvest loss, poor storage facility, difference in capsule maturity, and shattering.

Weed infestation is one of the major factors limiting the yield of sesame as its seedling growth is slow during the first four weeks, making it a poor competitor at earlier stages of the crop growth [2]. The early growth period of sesame is the most critical stage at which any kind of stress can affect the economic yields. Sesame is very sensitive to weeds from emergence up to $4 \mathrm{WAE}$, which can cause $>80 \%$ yield loss [3]. Moreover, Upadhyay [4] has stressed that early growth stage of sesame is slow, thus suppressing the weed growth at 
crop establishing is important. The sesame growing areas of western Tigray are highly infested by different broadleaved weeds and grass weeds. A weed survey conducted by Humera Agricultural Research Center/HuARC ([5], unpublished work) revealed that more than 80 weed species were recorded and identified as weed pests for sesame. Of the weed pests, Commelina foecunda was the most dominant, abundant, and frequently occurred weed. This species is a weed of field crops, which grows competitively and easily. The invasive plant has a native range starting from Cameroon to Ethiopia and Botswana, Arabian Peninsula, and its synonym is Cyanotis foecunda (http:// plantsoftheworldonline.org/taxon/urn:lsid:ipni.org:names: 172477-1). According to the report by Isaac et al. [6], among the Commelina weeds, C. benghalensis, C. diffusa, and $C$. communis are the most troublesome weeds in the new world, Asia and tropical Africa. But now, C. foecunda is becoming the most noxious weed in north Ethiopia. The problem other than abundance and density with this weed is its difficulty to eradicate from the field if it once emerged. The weed C. foecunda was becoming a serious weed in around 2013 (Goitom Arafaine, personal communication). In the study area; weeds are harrowed by man power using simple tool called "Mewled" (Figure 1). The weed by its nature is very complex and uprooted, and every fragments of the weed can grow overnight, if left in the field. For this reason, the sesame fields which left free of weeds by harrowing or hand weeding become highly reinvaded within few days. A survey conducted for five years in the United States revealed that Commelina weeds were found as troublesome weeds in cotton, maize, and wheat production areas [7]. Therefore, a sesame field once infested with Commelina weeds can never be free of the weed unless weeded frequently or sprayed herbicides (if available). Broken vegetative cuttings of stems of the Commelina weeds are capable of rooting and reestablishing after cultivation or disking [8]. In their native geographical areas, that is, tropical Asia, Africa, and the Pacific Islands, invasive Commelina weeds grow as a perennial, but they can survive as an annual in temperate regions, and their seeds have variable dormancy and germination features; also, they have the capacity to redevelop from stem fragments [9]. Noxious Commelina weeds were first observed in the continental United States in 1928 as a common weed and now listed among the world's worst weeds, affecting more than 25 crops [8-10]. It is a rainy season weed, requiring moist soil conditions for establishment and survives dry soil conditions after establishment [11]. Germination of aerial and subterranean seeds of C. benghalensis occurred at 25 and $30^{\circ} \mathrm{C}$, but no germination occurred below $18^{\circ} \mathrm{C}[8]$.

Both large-scale and small-scale sesame producers from different corners of the western Tigray rise questions about the complex weed C. foecunda in different workshops and discussions. Although the severity of the weed is observable, its distribution and coverage in the sesame growing area is not studied yet. The purpose of this study was to assess the distribution of C. foecunda and quantify its infestations in different sesame growing arrears of western Tigray.



Figure 1: The simple tool "Mewled" used for harrowing and weeding.

\section{Materials and Methods}

The assessment was conducted in the 2017 cropping season in sesame farm lands of the sesame growing areas of the western zone of Tigray. About 24 representative sesame growing areas were selected systematically from the three districts of western Tigray (Figure 2). Two representative unharrowed farms were selected from each growing area/locality; in general, 48 sesame farms were assessed. Within the growing area, farms were about $3-5 \mathrm{~km}$ apart from each other. The sample was taken by throwing $0.5 \times$ $0.5 \mathrm{~m}$ quadrant five times (diagonally) in each farm. The survey was conducted in the early stage of the crop before flowering and after flowering in capsule setting stages. The C. foecunda in the quadrant was counted separately. In each farm, altitude and farm category (both large- and smallscale farmers are there in the study area; and at the time of sampling, each farm was noted if it was for small-farm owner or large-farm owner farmer) were recorded. According to Nkoa et al. [12], prevalence, frequency, abundance, and density were also recorded and calculated as follows:

(1) Prevalence: it simply measures the percentage of occurrence of the pest (C. foecunda) in the area (location) from where the samples have been taken:

$$
P=\frac{A}{N} * 100
$$

where $P=$ prevalence, $A=$ sesame farms that have $C$. foecunda, and $N=$ total sampled sesame farms.

(2) Frequency (constancy): it is the percentage of sampling units on which a particular weed species is found. It explains how often a weed species occurs in the survey area:

$$
F=\frac{W}{N} * 100
$$

where $F=$ frequency, $W=$ number of occurrences of a weed species, and $N=$ sample number or quadrant number. 




FIgURE 2: Map of the study area.

(3) Abundance: population density of weed species expressed as summation of the number of individuals of weed plants (C. foecunda) per sample number:

$$
A=\sum \frac{W}{N},
$$

Where $A=$ abundance; $\sum W=$ summation of number of individual C. foecunda per the samples, and $N=$ sample number.

(4) Density: population density of weed species expressed as the number of individuals of weed plants per unit area:

$$
D=\sum \frac{W}{S_{\mathrm{a}}},
$$

where $D=$ density, $\sum W=$ summation of number of individual C. foecunda per the samples, and $S_{\mathrm{a}}=$ sapling unit area.

\section{Results and Discussion}

3.1. Prevalence of C. foecunda in Western Tigray. The survey results indicated that about $91.7 \%$ (Figure 3) of the assessed sesame farms in western zone of Tigray were infested with $C$. foecunda. Sesame farms in Kafta Humera and Welkait districts were $100 \%$ positive to the weed, whereas the prevalence of the weed was about $50 \%$ in Tsegede (Figure 3). The weed C. foecunda did not appear in sesame fields ten years ago (personal observation) but now it has become a very problematic weed in sesame production. In 1998, C. benghalensis was present in Georgia but not considered a serious pest infesting cotton. However, by 2001, it had quickly become very problematic weed [13].

3.1.1. Frequency of C. foecunda. Based on the survey result, the weed frequently appeared in the districts of Kafta Humera and Welkait (>90\%), whereas sparse $(32.5 \%)$ occurrence was recorded in Tsegede Woreda. Particularly, $C$. foecunda was observed commonly in most of the growing areas in Kafta Humera except in Adebay and Maiweini (Table 1).

When frequency of $C$. foecunda was inspected between small- and large-scale sesame producers, more frequent observations $(100 \%)$ were recorded from the large-scale sesame producers' farm, whereas about $72 \%$ was recorded from small-scale farms (Figure 4). This indicates that the weed species might be disseminated through farm equipments (tractors, disc harrow, Mewled, etc.) and natural agents (flooding, birds, etc.). Most probably, farm equipments could be the most contributors for the weed transmission among the large-scale sesame producers. For example, daily laborers use a permanent tool "Mewled" for harrowing in different farms; when weeding is completed in the first farm (in a large-scale farm), they go to another farm with their "Mewled." The same is true for tractors and disc harrows during planting time. In the other way, small-scale farmers also harrow their sesame using "Mewled" but the tool is not mobile from farm to farm, because they did it themselves using their own tools.

Shallow depth of tillage could be the other reason for higher weed frequency. Large-scale sesame producer usually use disc harrow (no more than $5 \mathrm{~cm}$ deep) for plowing, and the disc itself may aggravate the weeds intensity by cutting and dropping here and there, while small 


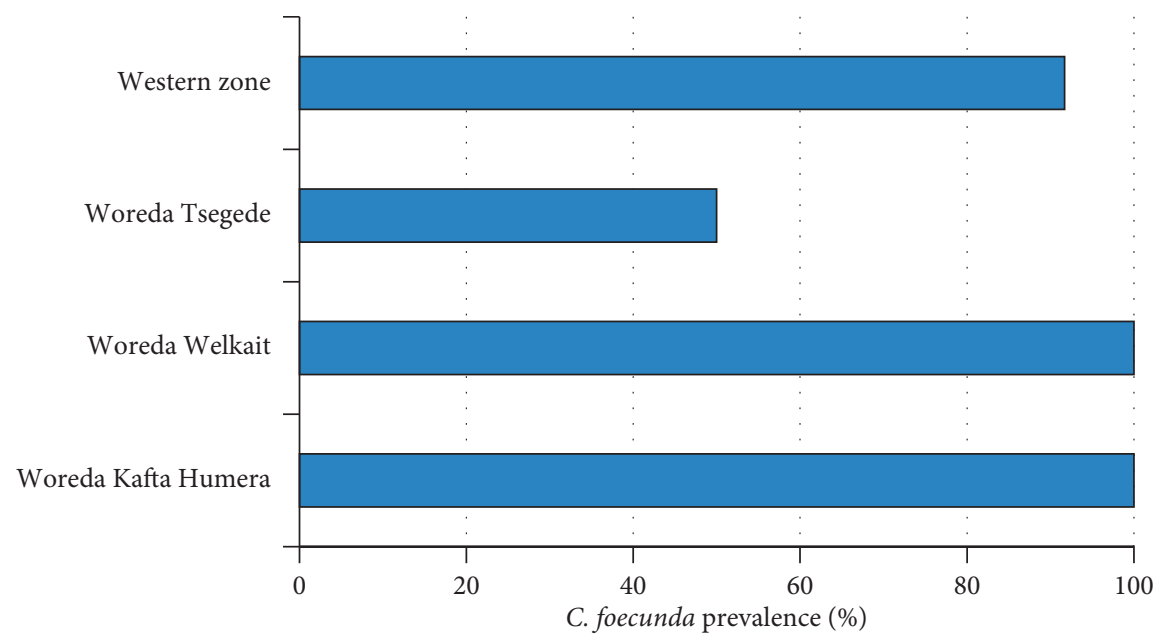

Figure 3: Prevalence of C. foecunda in sesame farms of western Tigray.

TAble 1: Frequency, abundance, and density of C. foecunda in different districts and growing areas of western Tigray.

\begin{tabular}{|c|c|c|c|c|}
\hline Woreda & $\begin{array}{c}\text { Growing } \\
\text { areas }\end{array}$ & $\begin{array}{c}\text { Frequency } \\
(\%)\end{array}$ & Abundance & $\begin{array}{c}\text { Density } \\
\left(\mathrm{m}^{2}\right)\end{array}$ \\
\hline \multirow{18}{*}{$\begin{array}{l}\text { Kafta } \\
\text { Humera }\end{array}$} & Adebay & $60 \mathrm{~b}$ & $22 \mathrm{abc}$ & $352 \mathrm{abc}$ \\
\hline & Adigoshu & $90 \mathrm{bc}$ & $37.2 \mathrm{a}-\mathrm{e}$ & $595.2 \mathrm{a}-\mathrm{e}$ \\
\hline & Bahker & $100 c$ & $46.5 \mathrm{a}-\mathrm{f}$ & $744 a-f$ \\
\hline & Banat & $100 c$ & $71.1 \mathrm{c}-\mathrm{g}$ & $1137.6 c-g$ \\
\hline & Bowal & $100 c$ & $45.8 \mathrm{a}-\mathrm{f}$ & $732.8 \mathrm{a}-\mathrm{f}$ \\
\hline & Central & $100 c$ & $75 \mathrm{~d}-\mathrm{g}$ & $1200 d-g$ \\
\hline & Hagre selam & $90 \mathrm{bc}$ & $19.6 \mathrm{abc}$ & $313.6 \mathrm{abc}$ \\
\hline & Lugdi & $100 c$ & $75.3 \mathrm{~d}-\mathrm{g}$ & $1204.8 \mathrm{~d}-\mathrm{g}$ \\
\hline & Maikadra & $90 \mathrm{bc}$ & $21.3 \mathrm{abc}$ & $340.8 \mathrm{abc}$ \\
\hline & Maisegen & $100 c$ & $57.4 \mathrm{~b}-\mathrm{g}$ & $918.4 \mathrm{~b}-\mathrm{g}$ \\
\hline & Maitemen & $100 c$ & $61.3 \mathrm{~b}-\mathrm{g}$ & $980.8 \mathrm{~b}-\mathrm{g}$ \\
\hline & Maiweini & $60 \mathrm{~b}$ & $24.1 \mathrm{a}-\mathrm{d}$ & $385.6 \mathrm{a}-\mathrm{d}$ \\
\hline & Niguara & $100 c$ & $107.7 \mathrm{gh}$ & $1723.2 \mathrm{gh}$ \\
\hline & Rawian & $100 c$ & $86.9 \mathrm{e}-\mathrm{h}$ & $1390.4 \mathrm{e}-\mathrm{h}$ \\
\hline & Shelela & $100 c$ & $132.8 \mathrm{~h}$ & $2124.8 \mathrm{~h}$ \\
\hline & Sherifhamed & $100 c$ & 79.6efg & $1273.6 \mathrm{efg}$ \\
\hline & Whdet & $100 c$ & $102 \mathrm{gh}$ & $1632 \mathrm{gh}$ \\
\hline & Mean & $93.5 \mathrm{~B}$ & $62.7 \mathrm{~B}$ & 1002.9B \\
\hline \multirow{4}{*}{ Welkait } & Maigaba & $100 c$ & 95.7fgh & 1531.2fgh \\
\hline & Qorarit & $80 \mathrm{bc}$ & $43.2 \mathrm{a}-\mathrm{e}$ & $691.2 \mathrm{a}-\mathrm{e}$ \\
\hline & Mogue & $90 \mathrm{bc}$ & $14.6 \mathrm{ab}$ & $233.6 \mathrm{ab}$ \\
\hline & Mean & $90 \mathrm{~B}$ & $51.2 \mathrm{AB}$ & 818.7AB \\
\hline \multirow{5}{*}{ Tsegede } & Kebabo & $100 c$ & $68.3 c-g$ & $1092.8 \mathrm{c}-\mathrm{g}$ \\
\hline & Maidelie & $20 \mathrm{a}$ & $0.3 a^{\circ}$ & $4.8 \mathrm{a}$ \\
\hline & Zuriadansha & $10 \mathrm{a}$ & $0.1 \mathrm{a}$ & $1.6 \mathrm{a}$ \\
\hline & Rubalemin & $0 \mathrm{a}$ & $0 \mathrm{a}$ & $0 \mathrm{a}$ \\
\hline & Mean & $32.5 \mathrm{~A}$ & $17.2 \mathrm{~A}$ & $274.8 \mathrm{~A}$ \\
\hline \multicolumn{2}{|c|}{ Grand mean } & 82.9 & 53.7 & 859 \\
\hline \multicolumn{2}{|c|}{$\mathrm{SE}$} & 19.33 & 25.02 & 400.2 \\
\hline \multicolumn{2}{|l|}{ CV (\%) } & 23.3 & 46.6 & 46.6 \\
\hline \multicolumn{2}{|c|}{ LSD $(0.05)$} & 39.98 & 51.75 & 828 \\
\hline
\end{tabular}

Means followed by the same letters are not statistically different from each other $(p<0.01)$; capital letters indicate Woreda; small letters indicate sesame growing area.

scale farmers most probably use oxen drawn "Mahresha" ( $>10 \mathrm{~cm}$ deep) for plowing. Commelina weeds can produce seeds and can regenerate from fragmented stems $[9,14]$.



Figure 4: Distribution of C. foecunda in small- and large-scale sesame producers of western Tigray.

Therefore, shallowly buried seeds and stem fragments could emerge easily and densely, whereas the deeply buried ones might not.

3.1.2. Abundance and Density of C. foecunda. Abundance and density of C. foecunda in western zone of Tigray were 53.7 and $859 / \mathrm{m}^{2}$, respectively. The weed occurred richly and tightly in Kafta Humera district, whereas it was poor and irresolute in Tsegede. Growing areas with maximum abundance of the weed were Niguara (107.7), Rawian (86.9), Shelela (132.8), Sherifhamad (79.6), Banat (71.1), Lugudi (75.3), Centeral (75), Whdet (102), and Kebabo (68.3) (all in Kafta Humera district except Kebabo). While Rubalemin, Zuriadansha, Maidelie, Mogue, and Adebay (Welkait and Tsegede districts) have lower $(<15)$ weed abundances. Areas with higher $(>60)$ abundance were also with higher weed density $\left(>1000 / \mathrm{m}^{2}\right)($ Table 1$)$. Most of the growing areas mentioned under the higher infestation of the weed are areas under semimechanized farming. And therefore, farm equipments and shallow plowing depths might have great contribution for higher weed abundance in these areas. Higher rate of stem fragments might occur in the semimechanized farms than the oxen plowed farms. Shallowly buried $(2-4 \mathrm{~cm})$ seeds and stem fragments have higher rate 
of germination and regrowth capacity, respectively [14], and early emerged weeds can produce seeds in about 45 days, in which they may germinate two weeks later also [8]. This means Commelina weeds may have two generations in a single sesame production season before the crop was going harvested. Therefore, these factors make the weed very abundant and dense in kafta Humera sesame growing areas. On the contrary, almost all small-scale farms are selfmanaged, and everything is done on time properly, i.e., removal of uprooted and fragmented weeds from sesame field to uncultivated land, and the deep tilling practice helps also to minimize weed population. Above ground development of the noxious Commelina weeds are restricted at $6 \mathrm{~cm}$ depth [14]. Similarly, there was no seedling emergence at soil depth of $10 \mathrm{~cm}$ for the noxious Commelina weeds [15]. In the other way, abundance and density of $C$. foecunda is higher in lower altitudes compared to higher altitudes (>1000 m) (Figure 5). Germination and development of $C$. benghalensis favor higher temperature (but below $45^{\circ} \mathrm{C}$ ) [14]. And thus, the sesame growing areas in Kafta Humera are warmer (lower altitude) than the growing areas in Welkait and Tsegede.

\subsection{Distribution of C. foecunda across Sesame Producers'} Farm. Concentrated frequency, abundance, and density of the weed were recorded in large-scale sesame producers, whereas it was limited in the small-scale farms (Figure 4). Therefore, C. foecunda was highly distributed and expanded in the farms of large-scale producers compared to the smallscale producers. This might be because of the farm equipments which are being used exchangeably among the largescale farms and also due to the lower geographical locations of the large-scale farms which might be favorable for the weed growth. Furthermore, the farm management in general and weed management specifically in the growing areas is better in the small-scale producers' farms than the large scale producers' farms. This is because of the difficulty of managing the large-scale farms without mechanization. Most of the growing areas in Kafta Humera with higher weed infestation (Table 1) were under semimechanized production, where exchangeable farm equipment usage and shallow plowing depths are available. Germination and development of Commelina seeds favor higher temperature $\left(30-35^{\circ} \mathrm{C}\right)$ $[14,16]$. Moreover, the growth and reproduction rates of the weed under higher temperature were very fast [9]. And germination percentage and population stand of C. foecunda were very high at lower soil depth $(<5 \mathrm{~cm})$ [15]. Goddard et al. [17] reported that large number of mourning doves and other bird species that visit cropland help in dispersal and expansion of $C$. benghalensis.

\subsection{Distribution ofC. foecunda across Different Altitudes of the} Growing Areas. Sesame grows 500-1500 meter above the sea level in western Tigray/north Ethiopia. And the major weed of sesame C. foecunda was observed also to be growing in all areas in which sesame can grow (Table 1). Frequency of the weed was similar among lower, middle, and higher altitudes of sesame growing areas. But both abundance and density of



FIgURE 5: Distribution of C. foecunda across different altitudes of the growing areas.

C. foecunda were steeply increased from higher altitude to the lower altitudes (Figure 5). Perhaps, the weed might favor high temperature and limited moisture, since the lower altitudes areas are described with low rainfall and high temperatures. Unfortunately, most of the lower altitude growing areas are areas with large-scale or semimechanized farms. And large-scale farms were the severely infested ones (Figure 4). Commelina weeds (C. benghalensis) require higher temperature for germination, development, and fast reproduction, and it can resist moisture stress after establishment $[9,14]$.

\subsection{Distribution of C. foecunda across Sesame Growth Stages.} When we examine the infestation of $C$. foecunda weed between the early and late growth stage of sesame, the early growth stage (before flower initiation) of the crop recurrently, abundantly, and densely infested compared to the late growth stage (Figure 6). Sesame is more sensitive to weeds during the first 4 weeks [3] as sesame grows very slowly in the early stages and weeds get the chance to grow vigorously. Moreover, Duary and Hazra [18] reported that sesame should be free of weeds 15 to 45 days after sowing (DAS). The authors added that $10 \%$ yield increment could be also obtained if the field is kept weed free 15 to 60 DAS. Similarly, the conventional weeding practice for sesame in the study area is weeding twice before flowering and once after flowering (optional) but not during flowering. Hence, even though the degree of severity is too different sesame could be affected by the presence of weeds up to 60 DAS. On the other way, the lower C. foecunda infestation in the late growth stage (capsule setting) of sesame could be because of weed removal or hand weeding. As already mentioned above, weeding practice in the study area starts two weeks after emergence (WAE) up to six WAE (sometimes up to eight WAE but optional). In addition, the weed starts dying after 45 days due to senescence. And these reasons minimized abundance and density of the weed to a certain level but could not exterminate. An experiment conducted in the same area (Humera) stated that 2-3 hand weeding is optimal 


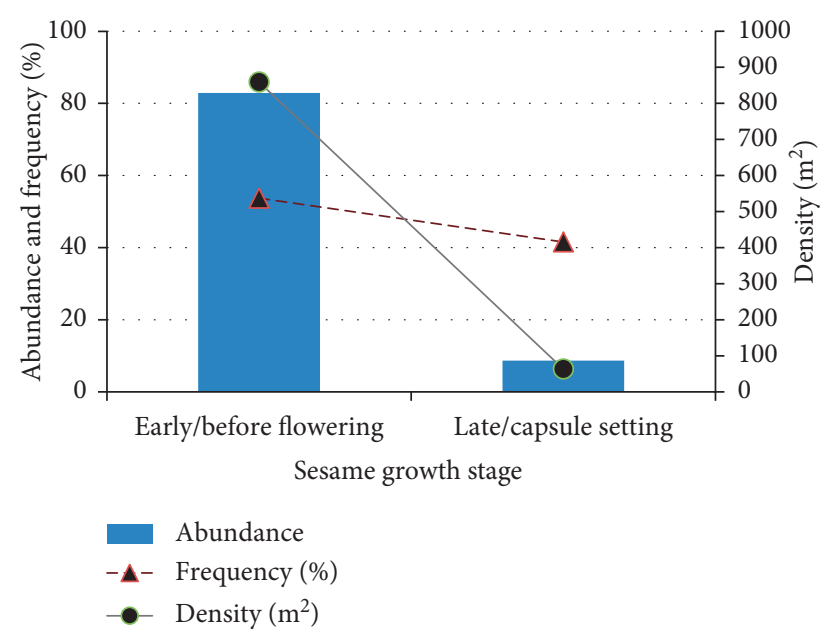

FIgURE 6: Distribution of C. foecunda in early and late sesame growing stages.

to keep the farm clean and can save more than $80 \%$ sesame yield losses [3]. But, occurrence of C. foecunda infestation still in the farm after two hand weeding was an indication of how the weed is worthy.

\section{Conclusion}

The survey result showed that about $91.7 \%$ of the assessed sesame farms in western Tigray were found infested with $C$. foecunda. Frequency, abundance, and density of $C$. foecunda in western Tigray were found to be $82.9 \%, 53.7$, and $859 \mathrm{~m}^{-1}$, respectively. The weed frequently appeared in Kafta Humera compared to Welkait and Tsegede. And, it occurred abundantly and closely in Kafta Humera growing areas also, whereas it occurred poorly and irresolutely in Tsegede. Concentrated frequency, abundance, and density of the weed were recorded in large-scale sesame producers' farms, in lower sesame growing altitudes, and early growth stage of sesame. And, it was limited in the small-scale farms, in higher sesame growing altitudes, and later growth stage of sesame. Since, the noxious weed has wide area coverage and distribution in western Tigray, its control method has to be developed soon.

\section{Data Availability}

The data used to support the findings of this study are available from the corresponding author upon request.

\section{Conflicts of Interest}

The authors declare that there are no conflicts of interest regarding the publication of this paper.

\section{Acknowledgments}

The authors are grateful to the Tigray Agricultural Research Institute and Ethiopian Institute of Agricultural Research for the financial support, and they would like to extend their acknowledgements to all researchers of Humera Agricultural Research Center for their nice matching and expertise.

\section{References}

[1] E. A. Weiss, Oilseed Crops, Blackwell Science, Hoboken, NJ, USA, 2000.

[2] M. Bennett and B. Katherine, "Code, sesame recommendation for the northern territory agnote," vol. 657, no. 22, pp. 1-4, 2003.

[3] A. Mizan, "Estimation of critical period for weed control in sesame (Sesamum indicum L.) in northern Ethiopia," Ethiopian Journal of Science and Technology, vol. 2, no. 1, pp. 59-66, 2011.

[4] U. C. Upadhyay, Weed Management in Oilseed Crops in Oilseed Production Constraints and Opportunities, H. C. Srivastava, S. Bhasharan, B. Vatsya, and K. K. G. Menon, Eds., Oxford and IBH Publishing Company, New Delhi, India, 1985.

[5] HuARC, Survey and Identification of the Major Weeds in Sesame Farm in the Sesame Growing Areas of Ethiopia, Tigray Agricultural Research Institute, HuARC, Mek'ele, Ethiopia, 2017.

[6] W.-A. Isaac, Z. Gao, and M. Li, "Managing Commelina species: prospects and limitations," in Herbicides-Current Research and Case Studies in Use, IntechOpen Limited, London, UK, 2013.

[7] T. M. Webster and R. L. Nichols, "Changes in the prevalence of weed species in the major agronomic crops of the Southern United States: 1994/1995 to 2008/2009," Weed Science, vol. 60, no. 2, pp. 145-157, 2012.

[8] T. M. Webster, M. G. Burton, A. Stanley Culpepper, A. C. York, and E. P. Prostko, "Tropical spiderwort (Commelina benghalensis): a tropical invader threatens agroecosystems of the southern United States," Weed Technology, vol. 19, no. 3, pp. 501-508, 2005.

[9] M. K. Riar, D. S. Carley, C. Zhang et al., "Environmental influences on growth and reproduction of invasive Commelina benghalensis," International Journal of Agronomy, vol. 2016, Article ID 5679249, 9 pages, 2016.

[10] A. S. Culpepper, J. T. Flanders, A. C. York, and T. M. Webster, "Tropical spiderwort (Commelina benghalensis) control in glyphosate-resistant cotton," Weed Technology, vol. 18, no. 2, pp. 432-436, 2004.

[11] V. Kaul, N. Sharma, and A. K. Koul, "Reproductive effort and sex allocation strategy in Commelina benghalensis L., a common monsoon weed," Botanical Journal of the Linnean Society, vol. 140, no. 4, pp. 403-413, 2002.

[12] R. Nkoa, M. D. K. Owen, and C. J. Swanton, "Weed abundance, distribution, diversity, and community analyses," Weed Science, vol. 63, no. 1, pp. 64-90, 2015.

[13] T. M. Webster and G. E. MacDonald, "A survey of weeds in various crops in Georgia," Weed Technology, vol. 15, no. 4, pp. 771-790, 2001.

[14] M. K. Riar, J. F. Spears, J. C. Burns, D. L. Jordan, C. Zhang, and T. W. Rufty, "Persistence of Benghal dayflower (Commelina benghalensis) in sustainable agronomic systems: potential impacts of hay bale storage, animal digestion, and cultivation," Agroecology and Sustainable Food Systems, vol. 38, no. 3, pp. 283-298, 2014.

[15] M. Matsuo, H. Michinaga, H. Terao, and E. Tsuzuki, “Aerial seed germination and morphological characteristics of juvenile seedlings in Commelina benghalensis L," Weed Biology and Management, vol. 4, no. 3, pp. 148-153, 2004. 
[16] M. H. Sabila, T. L. Grey, T. M. Webster, W. K. Vencill, and D. G. Shilling, "Evaluation of factors that influence Benghal dayflower (Commelina benghalensis) seed germination and emergence," Weed Science, vol. 60, no. 1, pp. 75-80, 2012.

[17] R. H. Goddard, T. M. Webster, R. Carter, and T. L. Grey, "Resistance of Benghal dayflower (Commelina benghalensis) seeds to harsh environments and the implications for dispersal by mourning doves (Zenaida macroura) in Georgia, USA," Weed Science, vol. 57, no. 6, pp. 603-612, 2009.

[18] B. Duary and D. Hazra, "Determination of critical period of crop-weed competition in sesame," Indian Journal of Weed Science, vol. 45, no. 4, pp. 253-256, 2013. 


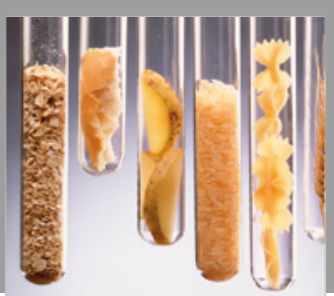

International Journal of Food Science

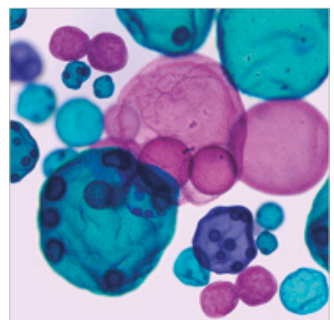

International Journal of Microbiology
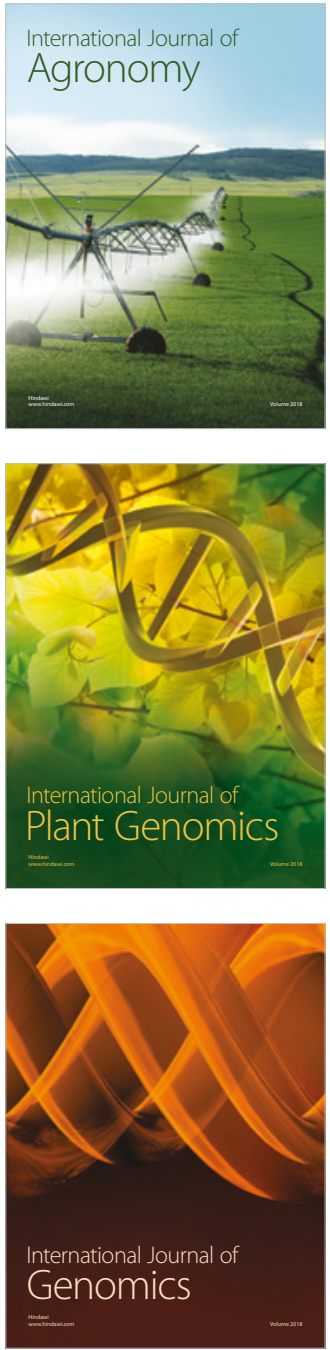

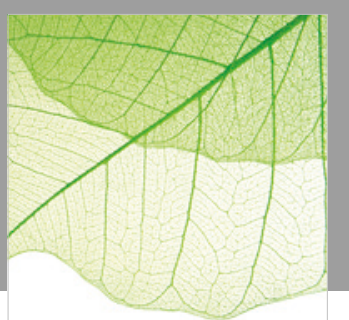

Journal of Botany
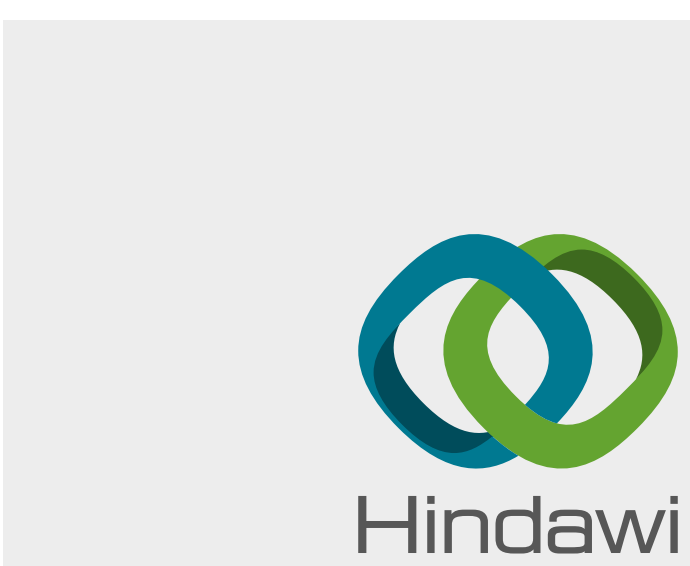

Submit your manuscripts at

www.hindawi.com


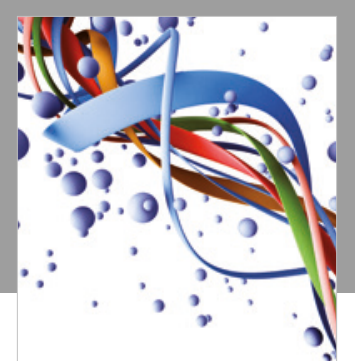

Scientifica

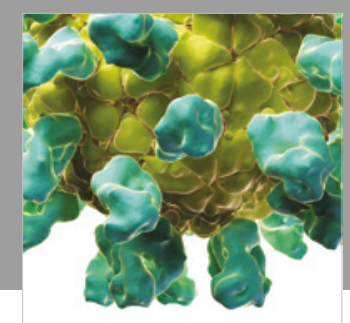

Veterinary Medicine International



The Scientific World Journal
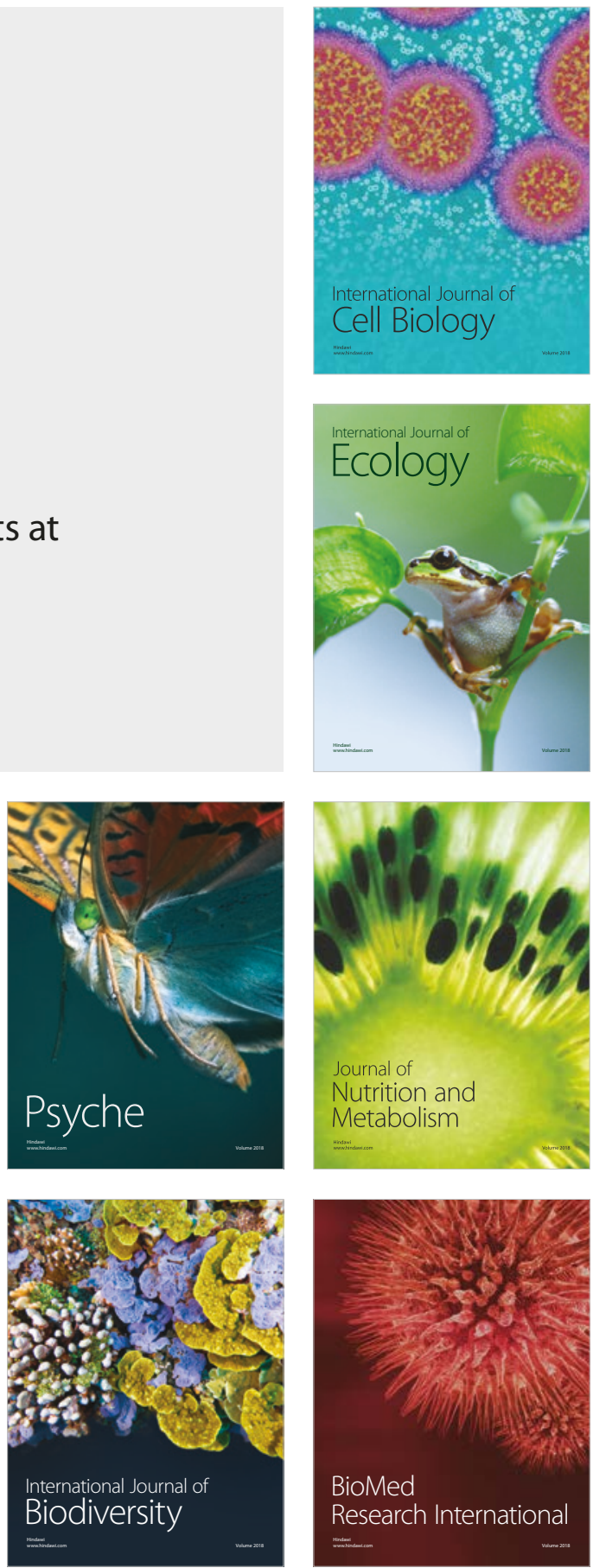